\title{
Potent Adjuvantic Activity of a CCR1-agonistic Bis-Quinoline
}

\author{
Rehman Ukani, Tyler C. Lewis, Timothy P. Day, Wenyan Wu, Subbalakshmi S. Malladi, \\ Hemamali J. Warshakoon, and Sunil A. David \\ Department of Medicinal Chemistry, University of Kansas, Lawrence, KS 66047
}

\begin{abstract}
A bis-quinoline compound, (7-chloro- $N$-(4-(7-chloroquinolin-4-ylamino)butyl)quinolin-4-amine; RE-660) was found to have C-C chemokine receptor type 1 (CCR1)-agonistic properties.RE-660 displayed strong adjuvantic activity in mice when co-administered with bovine $\alpha$-lactalbumin used as a model subunit protein antigen. RE-660 evoked a balanced Th1 (IgG2)/Th2 (IgG1) antibody profile, and the quality of antibodies elicited by the bis-quinoline was found to be superior to that evoked by glucopyranosyl lipid A by surface plasmon resonance experiments. No evidence of proinflammatory activity was observed in human blood ex vivo models. In preliminary acute toxicity studies, the compound was found to be of lower toxicity than chloroquine in mice, and was non-mutagenic in an Ames screen.
\end{abstract}

\section{Keywords}

Vaccines; Adjuvants; Bis-quinolines; CCR1; Cytokines

Since the discovery of adjuvanticity of aluminum salts by Glenny and coworkers, ${ }^{1}$ aluminum salt-based mineral salts ("alum") have, until the recent introduction of monophosphoryl lipid A (MPL), ${ }^{2}$ remained the only adjuvants currently approved by the FDA. Aluminum salts are weak adjuvants, promoting Th2-skewed, rather than Th1-biased humoral responses. ${ }^{3}$ They are ineffective at inducing cytotoxic T lymphocyte (CTL) or mucosal IgA antibody responses, and exhibit the propensity of inducing IgE isotypes, ${ }^{3}$ the basis of which is just beginning to be understood ${ }^{4}$. The rapid convergence of innate immunity, ${ }^{5}$ and the nascent field of TLRs (toll-like receptors), ${ }^{6}$ and other PathogenAssociated Molecular Pattern (PAMP)-recognizing elements ${ }^{7}$ are expected to contribute significantly not only to the discovery and design of novel adjuvants, but also to their rapid evaluation of potency and, importantly, safety. ${ }^{8}$

In an effort to aid the evaluation of both adjuvantic potency and proinflammatory activities of relatively large focused libraries of compounds being generated by our synthetic programs, we have adopted an approach that encompasses a detailed 'immunoprofiling' of representative members of known TLR agonists, $9 ; 10$ as well as elucidating structure-activity relationships of promising chemotypes. ${ }^{11-13}$ We report in this paper that simple, synthetically facile, bis-quinoline compounds possess immunostimulatory and adjuvantic properties without any apparent proinflammatory activity, and inducing robust, Th1-biased

(C) 2011 Elsevier Ltd. All rights reserved

Publisher's Disclaimer: This is a PDF file of an unedited manuscript that has been accepted for publication. As a service to our customers we are providing this early version of the manuscript. The manuscript will undergo copyediting, typesetting, and review of the resulting proof before it is published in its final citable form. Please note that during the production process errors may be discovered which could affect the content, and all legal disclaimers that apply to the journal pertain.

Supplementary Material Experimental methods. 
humoral responses in murine models. In contradistinction to our previous work on vaccine adjuvants, this discovery was entirely accidental.

Our desire in evaluating TLR7/8 agonists as potential vaccine adjuvants ${ }^{11 ; 12 ; 14}$ had also engendered an interest in TLR7/8 antagonists, ${ }^{15 ; 16}$ because aside from its potential therapeutic applications, ${ }^{17 ; 18}$ we had hoped that we may glean from those molecules such structural features as would be best avoided for purposes of designing and developing potent adjuvants. We ${ }^{15}$ and others ${ }^{19}$ had observed that chloroquine selectively inhibits TLR7 signaling and, given that most TLRs signal via homo- or hetero-dimerization, ${ }^{20}$ we were curious to examine dimeric 7-chloroquinolines, a chemotype that had previously been evaluated for anti-malarial activity (Fig. 1). ${ }^{21}$

We found to our surprise that several bis-quinolines, but neither piperaquine nor chloroquine, induced in apparently non-specific manner, NF- $\mathrm{KB}$ transactivation in virtually all of our reporter cell lines (HEK-293 cells stably transfected with TLR2, TLR3, TLR4, TLR5, TLR7, TLR8, TLR9, or Nod-1, and an NF-kB-secreted alkaline phosphatase [NF$\kappa B-S E A P]$ reporter gene; data not shown). Experiments with control (null) HEK-293 cells stably transfected only with NF-אB-SEAP also yielded virtually identical results, with the maximal response observed for RE-660 with a tetramethylene spacer bridging the quinoline moieties (Fig. 2). The origin of the distinctly biphasic nature of NF- $\mathrm{KB}$ induction (Fig. 2) has been observed for several immunostimulatory chemotypes ${ }^{11-13}$ is unclear, but was verified not to be a consequence of cytotoxicity.

RE-660 showed no detectable proinflammatory (TNF- $\alpha$, IL-1 $\beta$, IL-6, IL-8, IL-12, IL-18) or anti-inflamatory (IL-10) responses in whole human blood up to concentrations of $50 \mu \mathrm{M}$, whereas LPS (TLR4 agonist), ${ }^{9}$ a dual TLR7/8 imidazoquinoline agonist that we had characterized earlier, ${ }^{12}$ as well as CL-075 (TLR8 agonist), ${ }^{9}$ showed robust induction of all of the above cytokines as previously described by us. Transcriptomal profiling in human peripheral blood mononuclear cells also did not reveal any discernible signatures of inflammation or immune activation (data not shown). A careful examination of the literature indicated that certain bis-quinolines bind to zinc, ${ }^{22}$ and that such metal-bound ligands can allosterically modulate chemokine receptor activity. ${ }^{23}$ RE-660, however, displayed no propensity to interact with any of a wide range of metals as adjudged by absorption and fluorescence spectroscopy, as well as by ${ }^{1} \mathrm{H}$ NMR.

We elected to empirically screen for chemokine receptor agonistic activity, and we were gratified to find that the compound was agonistic at CCR1 (C-C chemokine receptor type 1) with an $\mathrm{EC}_{50}$ value of $2 \mu \mathrm{M}$ (Fig. 3). No activity was detected with CCR2, CCR3, CXCR2, or CXCR4 screens.

Mindful of recent observations that proinflammatory activity is not an absolute prerequisite for adjuvantic properties, ${ }^{24}$ we decided to evaluate RE-660 in a murine model using bovine $\alpha$-lactalbumin as a test antigen despite the fact that the only tangible biomarker possibly associated with any potential immunostimulatory activity was its CCR1-agonistic profile. We deliberately chose to use outbred CF-1 mice that show neither the Th1 bias of C57/B16, nor the Th2 bias observed in Balb/c mice. ${ }^{25}$ In a meta-analysis of 4 independent experiments ( 5 animals per cohort, per experiment), RE-660 was found to have an adjuvantic activity comparable to that of glucopyranosyl lipid A (GLA), ${ }^{26 ; 27}$ a more potent analogue of monophosphoryl lipid A (MPL), as evidenced by near-superimposable anti- $\alpha$-lactalbumin IgG titers (Fig. 4A), and better than that of $\mathrm{PAM}_{2} \mathrm{CS}$, a prototype TLR2 agonist. ${ }^{13}$ Furthermore, we found in surface plasmon resonance experiments, that the quality of antibodies elicited by RE-660 was superior to that of both GLA and $\mathrm{PAM}_{2} \mathrm{CS}$, in terms of sensorgram responses (avidity) and dissociation kinetics (off-rates) (Fig. 4B). 
Importantly, RE-660, like GLA, evoked a balanced Th1 (IgG2)/Th2 (IgG1) antibody profile, whilst $\mathrm{PAM}_{2} \mathrm{CS}$, as expected, showed a dominant Th2 response (Fig. 5). In our preliminary evaluation of the safety of RE-660, no mutagenicity was detected in the standard Ames test. In an acute lethality model, no mortality was observed up to doses of $100 \mathrm{mg} / \mathrm{kg}$ of RE-660.

In conclusion, a bis-quinoline compound, possessing CCR1-agonistic activity, and bereft of any detectable proinflammatory-mediator inducing properties, was found to have potent adjuvantic activity in a murine model of immunization with a small, soluble model subunit protein antigen. However, we do not yet know if its adjuvantic property is causally related to its CCR1-agonistic activity, and whether its adjuvantic activity would be preserved in nonrodent species. We are excited, nonetheless, because the chemotype lends itself readily to extensive structure-activity relationship analyses.

\section{Supplementary Material}

Refer to Web version on PubMed Central for supplementary material.

\section{Acknowledgments}

This work was supported by NIH/NIAID contract HHSN272200900033C.

\section{References}

1. Glenny AT, Pope CG, Waddington H, Wallace V. J.Path.Bact. 1926; 29:38-45.

2. Garcon N, Segal L, Tavares F, Van Mechelen M. Vaccine. 2011; 29:4453-4459. [PubMed: 21527299]

3. Relyveld EH, Bizzini B, Gupta RK. Vaccine. 1998; 16:1016-1023. [PubMed: 9682353]

4. Marichal T, Ohata K, Bedoret D, Mesnil C, Sabatel C, Kobiyama K, Lekeux P, Coban C, Akira S, Ishii KJ, Bureau F, Desmet CJ. Nat.Med. 2011; 17:996-1002. [PubMed: 21765404]

5. Janeway CA Jr. Medzhitov R. Semin.Immunol. 1998; 10:349-350. [PubMed: 9799708]

6. Kawai T, Akira S. Semin.Immunol. 2007; 19:24-32. [PubMed: 17275323]

7. Thompson AJ, Locarnini SA. Immunol.Cell Biol. 2007; 85:435-445. [PubMed: 17667934]

8. Ahmed SS, Plotkin SA, Black S, Coffman RL. Sci.Transl.Med. 2011; 3:93rv2.

9. Hood JD, Warshakoon HJ, Kimbrell MR, Shukla NM, Malladi S, Wang X, David SA. Hum.Vaccin. 2010; 6:1-14.

10. Warshakoon HJ, Hood JD, Kimbrell MR, Malladi S, Wu WY, Shukla NM, Agnihotri G, Sil D, David SA. Hum.Vaccin. 2009; 5:381-394. [PubMed: 19270494]

11. Shukla NM, Malladi SS, Mutz CA, Balakrishna R, David SA. J.Med.Chem. 2010; 53:4450-4465. [PubMed: 20481492]

12. Shukla NM, Lewis TC, Day TP, Mutz CA, Ukani R, Hamilton CD, Balakrishna R, David SA. Bioorg.Med.Chem.Lett. 2011; 21:3232-3236. [PubMed: 21549593]

13. Wu W, Li R, Malladi SS, Warshakoon HJ, Kimbrell MR, Amolins MW, Ukani R, Datta A, David SA. J.Med.Chem. 2010; 53:3198-3213. [PubMed: 20302301]

14. Shukla NM, Mutz CA, Ukani R, Warshakoon HJ, Moore DS, David SA. Bioorg.Med.Chem.Lett. 2010; 20:6384-6386. [PubMed: 20933417]

15. Shukla NM, Malladi SS, Day V, David SA. Bioorg.Med.Chem. 2011; 19:3801-3811. [PubMed: 21620714]

16. Shukla NM, Kimbrell MR, Malladi SS, David SA. Bioorg.Med.Chem.Lett. 2009; 19:2211-2214. [PubMed: 19285861]

17. Fraietta JA, Mueller YM, Do DH, Holmes VM, Howett MK, Lewis MG, Boesteanu AC, Alkan SS, Katsikis PD. Antimicrob.Agents Chemother. 2010; 54:4064-4073. [PubMed: 20625151]

18. Mandl JN, Barry AP, Vanderford TH, Kozyr N, Chavan R, Klucking S, Barrat FJ, Coffman RL, Staprans SI, Feinberg MB. Nat.Med. 2008; 14:1077-1087. [PubMed: 18806803] 
19. Kuznik A, Bencina M, Svajger U, Jeras M, Rozman B, Jerala R. J.Immunol. 2011; 186:47944804. [PubMed: 21398612]

20. Botos I, Segal DM, Davies DR. Structure. 2011; 19:447-459. [PubMed: 21481769]

21. Vennerstrom JL, Ellis WY, Ager AL Jr. Andersen SL, Gerena L, Milhous WK. J.Med.Chem. 1992; 35:2129-2134. [PubMed: 1597862]

22. Mikata Y, Yamashita A, Kawamura A, Konno H, Miyamoto Y, Tamotsu S. Dalton Trans. 2009:3800-3806. [PubMed: 19417946]

23. Jensen PC, Thiele S, Ulven T, Schwartz TW, Rosenkilde MM. J.Biol.Chem. 2008; 283:2312123128. [PubMed: 18559339]

24. Smirnov D, Schmidt JJ, Capecchi JT, Wightman PD. Vaccine. 2011; 29:5434-5442. [PubMed: 21641953]

25. Watanabe H, Numata K, Ito T, Takagi K, Matsukawa A. Shock. 2004; 22:460-466. [PubMed: 15489639]

26. Coler RN, Bertholet S, Moutaftsi M, Guderian JA, Windish HP, Baldwin SL, Laughlin EM, Duthie MS, Fox CB, Carter D, Friede M, Vedvick TS, Reed SG. PLoS.ONE. 2011; 6:e16333. [PubMed: 21298114]

27. Lumsden JM, Pichyangkul S, Srichairatanakul U, Yongvanitchit K, Limsalakpetch A, Nurmukhambetova S, Klein J, Bertholet S, Vedvick TS, Reed SG, Sattabongkot J, Bennett JW, Polhemus ME, Ockenhouse CF, Howard RF, Yadava A. Infect.Immun. 2011; 79:3492-3500.

[PubMed: 21690242] 


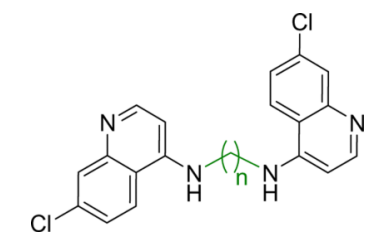

Figure 1.

Structures of the bis-quinoline compounds. 


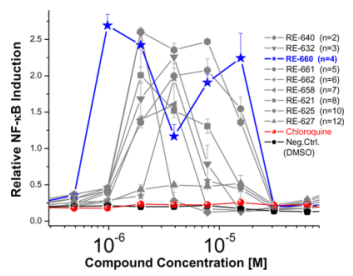

Figure 2.

$\mathrm{NF}-\kappa \mathrm{B}$ induction profiles by the bis-quinolines in a null-cell reporter gene assay (bottom). Means and sd (quadruplicates) of a single representative experiment are shown. 


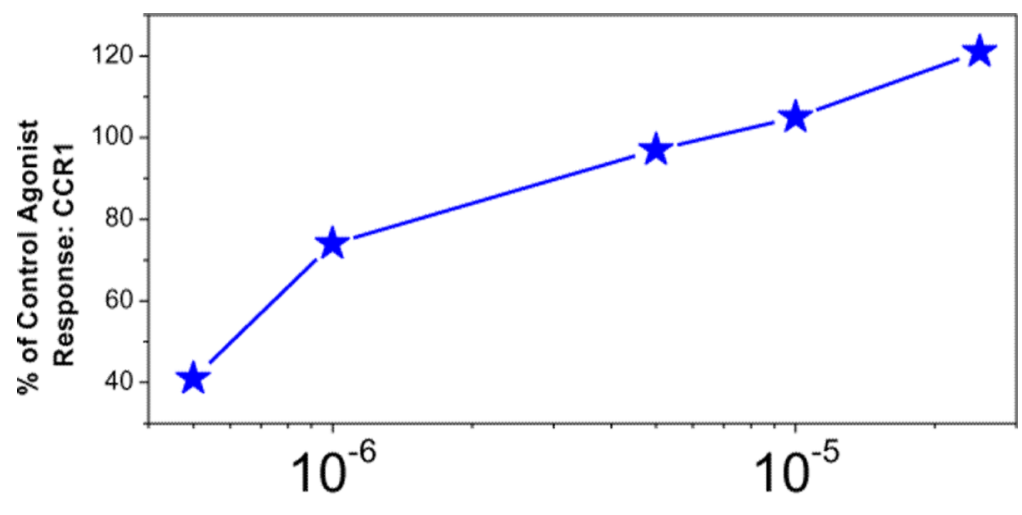

Concentration of RE-660 (M)

Figure 3.

Dose-response profile of CCR 1 agonism by RE-660 in CHO cells expressing hCCR1, and measured by cellular dielectric spectroscopy with $10 \mathrm{nM}$ human MIP- $1 \alpha$ as positive control. Means of duplicates of a representative experiment are shown. 


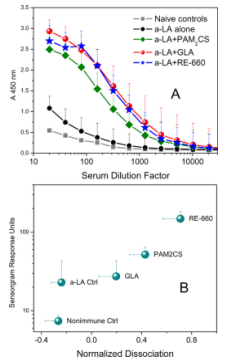

Figure 4.

A. Geometric means and geometric standard deviations of anti- $\alpha$-lactalbumin IgG (whole molecule) of four independent experiments conducted a month apart. Outbred CF-1 mice were used. Statistics are derived from 20 animals per cohort. B. Quality of antibody determined by dissociation kinetics and sensorgram adsorption kinetics derived from triplicate runs of surface-plasmon resonance experiments. 

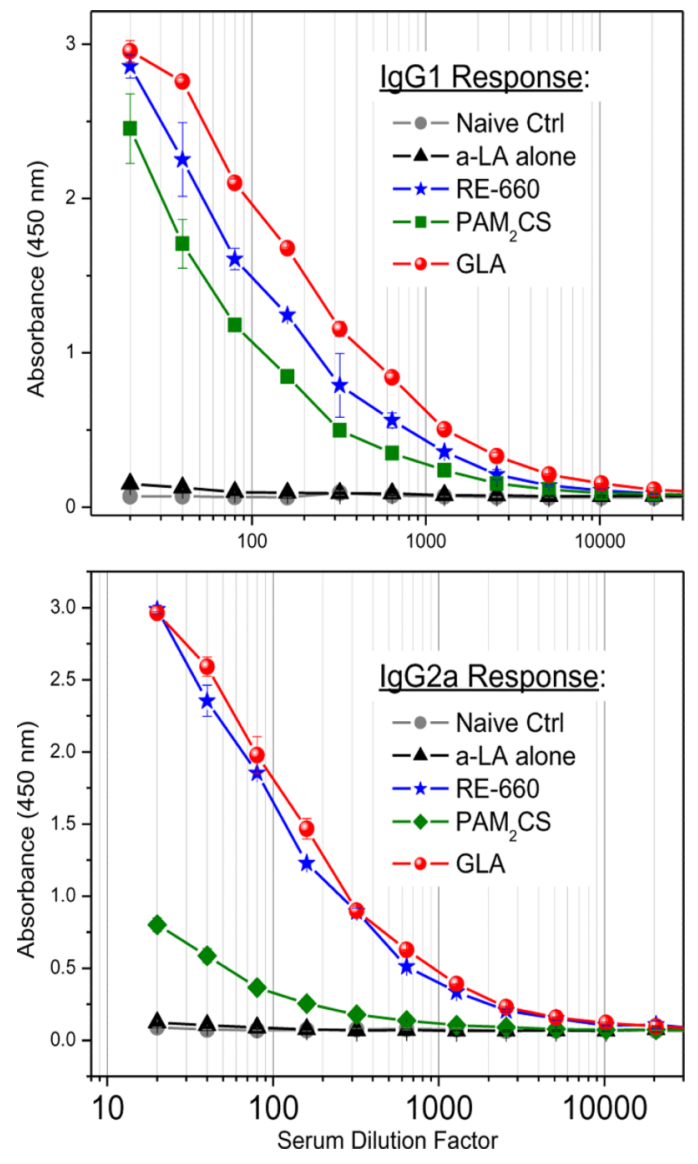

Figure 5.

Anti- $\alpha$-lactalbumin IgG1 and IgG2a titers followingimmunization.Cohorts of 5 outbred CF-1 mice per group wereimmunizedintramuscularlyon Day 0 with vehicle, $10 \mu \mathrm{g} / \mathrm{animal}$ of bovine $\alpha$-lactalbumin alone, or $10 \mu \mathrm{g}$ of $\alpha$-lactalbumin mixed with $50 \mu \mathrm{g}$ of either GLA, $\mathrm{PAM}_{2} \mathrm{CS}$, or RE-660 in a volume of $0.2 \mathrm{ml}$. Animals were boosted once on Day 14, and bled on Day 21. 